\title{
Penapisan Senyawa Antikanker dari Batang Brotowali (Tinospora crispa L) dan Uji Aktivitas Sitotoksik pada Kultur Sel WiDr
}

\section{Screening of Anticancer Compounds from Brotowali (Tinospora crispa L.) Bark and Cytotoxic Activity on WiDr Cells Culture}

\begin{tabular}{|c|c|}
\hline & ABSTRAK \\
\hline $\begin{array}{l}\text { Warsinah*, } \\
\text { Harwoko } \\
\text { *Jurusan Farmasi } \\
\text { Fakultas Ilmu-Ilmu Kesehatan } \\
\text { Universitas Jenderal Soedirman } \\
\text { warsinahapt@gmail.com }\end{array}$ & $\begin{array}{l}\text { Penelitian ini bertujuan untuk melakukan penapisan profil senyawa, uji } \\
\text { aktivitas sitotoksik, dan induksi apotosis dari ekstrak batang brotowali } \\
\text { (Tinospora crispa L.). Ekstraksi dilakukan dengan maserasi } \\
\text { menggunakan etanol 96\% kemudian di fraksinasi dengan } n \text {-heksan, } \\
\text { kloroform, etil asetat berdasarkan tingkat polaritas. Uji dilanjutkan } \\
\text { kromatografi lapis tipis menggunakan fase diam silika gel GF } 254 \text { dan } \\
\text { fase gerak campuran. Spot yang ada dilihat di bawah UV } 254 \mathrm{~nm} \text { dan } 366 \\
\text { nm serta disemprot dengan reagen penampak noda. Ekstrak dan fraksi } \\
\text { kemudian diuji aktivitas sitotosiknya dengan metode MTT, serta induksi } \\
\text { apoptosis dengan metode double staining dan flowcytometri. Hasil } \\
\text { penelitian menunjukkan bahwa ekstrak etanolik batang brotowali } \\
\text { mengandung senyawa flavanoid, fenolik, dan terpenoid. Ekstrak } \\
\text { mempunyai efek sitotoksik dengan IC } 50 \text { sebesar } 314 \mu \mathrm{g} / \mathrm{ml} \text { dan fraksi F3 } \\
\text { sebagai fraksi aktif mempunyai efek sitotoksik dengan IC50 sebesar } 148 \\
\mu \mathrm{g} / \text { ml. Pada konsentrasi } 25 \mu \mathrm{g} / \mathrm{ml} \text {, fraksi mampu menginduksi apoptosis } \\
\text { sebesar } 28,9 \% \text {, kontrol sel } 17,90 \% \text { dan doksorubisin } 63,12 \% \text {. Pemacuan } \\
\text { apoptosis ditunjukkan dengan adanya warna orange dan terjadinya } \\
\text { banyak badan apoptosis pada sel WiDr dengan perlakuan ekstrak yang } \\
\text { lebih banyak dibandingkan dengan kontrol sel. }\end{array}$ \\
\hline $\begin{array}{l}\text { Keywords: } \\
\text { Tinospora crispa, anticancer, cell } \\
\text { WiDr }\end{array}$ & $\begin{array}{l}\text { The purpose of this study is to screen and to evaluate cytotoxic activity } \\
\text { and apotosis induction of brotowali (Tinospora crispa) bark extract. } \\
\text { Brotowali barks were extracted by maceration using ethanol then } \\
\text { fractionated by using n-hexane, chloroform, ethyl acetate based on their } \\
\text { polarity. Fractions then were examined by thin-layer chromatography by } \\
\text { using the stationary phase silica gel GF } 254 \text { and the mobile phase } \\
\text { mixture. The presence of spot was detected under UV } 254 \text { nm and } 366 \\
n m \text {, then was sprayed by using staining reagent. Extract and fraction } \\
\text { were tested with MTT assay to evaluate cytotoxic activity, as well as } \\
\text { double staining and flowcytometri method to evaluate induction of } \\
\text { apoptosis. The results showed that the ethanolic extract of brotowali bark } \\
\text { contains compounds flavonoids, phenolics, steroids, and reductor } \\
\text { compounds. The extract and the active fraction (F3) have cytotoxic effects } \\
\text { with IC } 50 \text { value } 314 \mu \text { ml and } 148 \mu \text { glml, respectively. F3 concentration } \\
\text { at } 25 \mu g / m l \text { was able to induce apoptosis by } 28.9 \% \text {, compared to control } \\
\text { by } 17.90 \% \text { and doxorubicin by 63.12\%. Apoptosis induction was } \\
\text { indicated by the color orange and the occurrence of apoptosis bodies in } \\
\text { extract treatment compared to control cells. }\end{array}$ \\
\hline
\end{tabular}




\section{Pendahuluan}

Fenomena pergeseran pola hidup, termasuk perubahan pola makan dengan menu rendah serat dan tinggi kolesterol, akan terus menambah angka kejadian kanker kolon. Berdasarkan data dari National Cancer Institute, angka kematian kanker kolon diperkirakan lebih dari $33 \%$ pada tahun 2008 (Ries et al., 2004) dan di Amerika kanker kolon menempati peringkat tiga besar setelah kanker payudara dan kanker paru-paru (Calvert dan Frucht, 2002).

Beberapa usaha pengobatan kanker secara intensif telah dilakukan meliputi pengobatan secara fisik, pembedahan, maupun dengan senyawa kimia atau kemoterapi (Saphiro et al., 1999 dan Schneider et al., 1997). Namun usahausaha tersebut belum memberikan hasil yang memuaskan, sehingga perlu digali potensi bahan alam. Salah satu tanaman potensial untuk dikembangkan yaitu brotowali yang mengandung senyawa columbine, tinokrisposid, alkaloid, saponin, tanin, polifenol, pati, glikosida dan flavonoid (Triastuti, 2010)

Eksplorasi penelitian tanaman brotowali sebagai antikanker alami telah dilakukan Warsinah (2014), yang menunjukan bahwa ekstrak brotowali mempunyai aktivitas antiproliferatif terhadap sel kanker payudara (MCF7), HeLa, Caov-3 dan HepG2 (Zulkhairi et al., 2008). Berdasarkan penemuan adanya potensi antikanker pada tanaman brotowali (Tinospora crispa) tersebut, maka perlu dilakukan penelitian penapisan senyawa antikanker dari batang brotowali (Tinospora crispa) dan uji aktivitas pada kultur sel WiDr untuk mengungkap senyawa yang bertanggung jawab sebagai agen kemoterapi pada pengobatan kanker kolon.

\section{Bahan dan Metode}

\section{Bahan}

Bahan yang digunakan dalam penelitian adalah Batang brotowali diambil dari Kecamatan Baturraden, Kabupaten Banyumas, etanol (teknis), toluen (E. Merck), etil asetat (E. Merck), asam asetat (E. Merck), asam fosfo-molibdat, $\mathrm{KOH}$ etanolik, anisaldehida asam sulfat, amonia, dan sitroborat. Bahan untuk uji aktivitas antikanker kultur sel WiDr, medium RPMI 1640, MTT reagen (3(4,5-dimetiltiazol) 2,5-difeniltetrazolium bromide), reagen stopper, pereaksi akridine orange-etidium bromida, PBS dan kit aneksin V.

\section{Pembuatan simplisia}

Bahan yang diambil yaitu batang yang dicuci dengan air yang mengalir untuk menghilangkan kotoran yang menempel, kemudian dikeringkan dengan oven pada suhu $40-50^{\circ} \mathrm{C}$. Simplisia tersebut kemudian diserbuk menggunakan grinder.

\section{Pembuatan ekstrak}

Tanaman brotowali yang telah dibuat serbuk, ditimbang sebanyak 500 gram di ekstrak selama 3 x 24 jam menggunakan pelarut etanol dengan cara maserasi. Ekstrak disaring kemudian diuapkan dengan evaporator hingga didapatkan ekstrak bebas pelarut, kemudian ekstrak tersebut ditimbang (Harborne, 1987).

\section{Fraksinasi ekstrak etanol metode partisi}

Ekstrak difraksinasi dengan pelarut $n$ heksan, kloroform dan etil asetat menggunakan metode partisi dan dilanjutkan dengan kromatografi lapis tipis. Fraksi yang diperoleh kemudian 
diidentifikasi dengan reagen penampak noda dan diuji sitotoksiknya terhadap sel kanker WiDr dengan menggunakan metode MTT.

\section{Kromatografi lapis tipis}

Ekstrak etanolik dan masing-masing fraksi ditotolkan pada lempeng KLT silika gel F254. Kemudian dielusi dengan fase gerak toluen: etil asetat: asam asetat $(5: 4: 1)$ dan disemprot dengan pereaksi asam fosfomolibdat, kemudian diuapi amonia (Jork et al, 1989) dan pereaksi semprot $\mathrm{KOH}$ etanolik untuk mengetahui adanya kumarin (Machek, 1972). Untuk mengetahui golongan flavonoid, lempeng KLT diuapi dengan amonia dan disemprot dengan pereaksi sitroborat (Wagner et al, 1996), dan pereaksi anisaldehida asam sulfat untuk melihat senyawa lainnya.

\section{Uji aktivitas sitotoksik terhadap kultur} sel WiDr

Sel kanker WiDr ditanam dalam medium RPMI 1640 yang mengandung Lglutamin dan $10 \%$ fetal bovine serum, 100 unit $/ \mathrm{ml}$ penisilin dan $100 \mu \mathrm{g} / \mathrm{ml}$ streptomisin (Dai, 1998).

Uji sitotoksik dengan metode MTT (Febriansah et al., 2014)

Sebanyak $100 \mu \mathrm{l}$ suspensi sel WiDr dengan kepadatan $2 \times 10^{4} / 100 \quad \mu l$ didistribusikan ke dalam sumuran pada plat 96-sumuran, ditambah sampel uji dengan kadar masing-masing 1000 $\mu \mathrm{g} / \mathrm{ml}, 500 \mu \mathrm{g} / \mathrm{ml}, 250 \mu \mathrm{g} / \mathrm{ml}, 125 \mu \mathrm{g} / \mathrm{ml}$, $62,5 \mu \mathrm{g} / \mathrm{ml}$. Sebagai kontrol digunakan $100 \mathrm{ml}$ suspensi sel. Selanjutnya diinkubasi selama 24 jam pada suhu $37^{\circ} \mathrm{C}$. Setelah inkubasi ditambah $10 \mathrm{ml}$ campuran MTT $5 \mathrm{mg} / \mathrm{ml}$. Kemudian diinkubasi 4 jam pada suhu $37^{\circ} \mathrm{C}$. Reaksi
MTT dihentikan dengan reagen stopper. Kemudian diikubasi semalam pada suhu kamar, serapan dibaca dengan mikroplate reader pada panjang gelombang $550 \mathrm{~nm}$.

Uji induksi apoptosis melaluii pengecetan etidium bromida-akridin orange

Sel (kepadatan $1,5 \times 10^{4} \mathrm{sel} /$ sumuran) ditanam pada coverslips dalam plat 24sumuran sampai 50\% konfluen. Sehari sebelum perlakuan, medium diganti kemudian diinkubasi dengan senyawa uji selama 24 jam. Medium dalam sumuran diambil kemudian coverslips yang memuat sel diangkat, diletakan di atas objek glass dan ditambah dengan 10 $\mu$ campuran etidium bromida - akridin oranye, didiamkan selama 5 menit, dan segera diamati di bawah mikroskop flouresens.

Uji induksi apoptosis secara flowcytometri

Mikroplate 6 sumuran diisi dengan 500 $\mu 1$ suspensi sel dengan kepadatan $5 \times 10^{4}$, kemudian diinkubasi dalam inkubator $\mathrm{CO}_{2}$ pada suhu $37^{\circ} \mathrm{C}$. Sel diberi perlakuan $500 \mu \mathrm{l}$ fraksi kloroform dengan konsentrasi setengah $\mathrm{IC}_{50}$ atau doksorubisin $(1 \mu \mathrm{g} / \mathrm{ml})$ dan sebagai kontrol negatif ditambah media, kemudian diinkubasi lagi selama 24 jam. Pada akhir inkubasi, sel disentrifugasi selama 3 menit dengan kecepatan 3000 rpm. Supernatannya dibuang, pelet sel ditambah PBS dan diresuspensi. Suspensi dipindah ke dalam mikrotube dan disentrifugasi, selanjutnya supernatan dibuang, kemudian sel dipanen dengan tripsin. Sel dipindah ke mikrotube kemudian disentrifugasi selama 3 menit dengan kecepatan 3000 rpm, supernatan dibuang dan sel dibilas 
dengan PBS dan disentrifugasi lagi, kemudian PBS dibuang.

Endapan sel di dalam microtube kemudian difiksasi dengan etanol $70 \%$ pada $-20^{\circ} \mathrm{C}$, diinkubasi selama 30 menit pada suhu ruang kemudian disentrifugasi. Endapan dicuci dengan PBS sebanyak dua kali kemudian ditambahkan reagen PI dan aneksin V. Mikrotube dibungkus dengan aluminium foil dan diinkubasi dalam ruang gelap selama 15 menit. Suspensi sel dihomogenkan kemudian dipindah ke tabung flowcytometer dengan filter nilon, selanjutnya dianalisis dengan flowcytometer.

\section{Analisis data}

Data kromatogram hasil KLT dianalisis secara deskriftif kualitatif. Data yang didapat dari uji sitotoksisitas dihitung dengan rumus:

$$
\begin{gathered}
(\text { Abs P- Abs M) } \\
\% \text { kematian sel }=\text {------ } \times 100 \%
\end{gathered}
$$

(Abs K-Abs M)

Keterangan:

Abs P : absorbansi perlakuan

Abs K : absorbansi sel kontrol

Abs M : absorbansi media

Kemudian dilanjutkan analisis statistik dengan uji korelasi menggunakan persamaan garis regresi dan menentukan nilai $\mathrm{IC}_{50}$. Pada uji induksi apoptosis, data berupa morfologi sel, dibandingkan antara kontrol dan perlakuan sampel.

\section{Hasil dan Pembahasan}

\section{Ekstraksi, fraksinasi, dan profil KLT}

Simplisia batang brotowali yang di ekstrak dengan menggunakan etanol 96\% menghasilkan rendemen terhadap berat serbuk sebesar 13,23\% b/b. Hasil ini lebih besar dari hasil penelitian lain yaitu $12,10 \%$ (Irianti el al, 2011). Hal ini dapat disebabkan karena adanya pengaruh lingkungan hidup tanaman brotowali sebagai sampel yang dibuktikan dengan daerah pengambilan sampel yang berbeda.

Hasil ini juga lebih kecil dari pada rendemen ekstrak menggunakan etanol $70 \%$ yaitu sebesar $11,10 \% \quad \mathrm{~b} / \mathrm{b}$ (Warsinah et al., 2014). Hal ini kemungkinan karena senyawa yang terdapat pada batang brotowali lebih banyak yang bersifat polar dibanding senyawa non polarnya. Hasil fraksinasi (Tabel 1) diperoleh senyawa dengan jumlah yang besar cenderung ke senyawa polar.

Tabel 1. Hasil pengelompokkan fraksi

\begin{tabular}{cccc}
\hline No & Fraksi & $\begin{array}{c}\text { Berat Fraksi } \\
(\mathrm{mg})\end{array}$ & Warna \\
\hline 1 & n-heksan & 156 & kuning \\
2 & kloroform & 497 & Hijau \\
3 & etilasetat & 212 & $\begin{array}{c}\text { Kuning } \\
\text { lemah } \\
\text { Coklat tua }\end{array}$ \\
\hline & residu & 3430 &
\end{tabular}
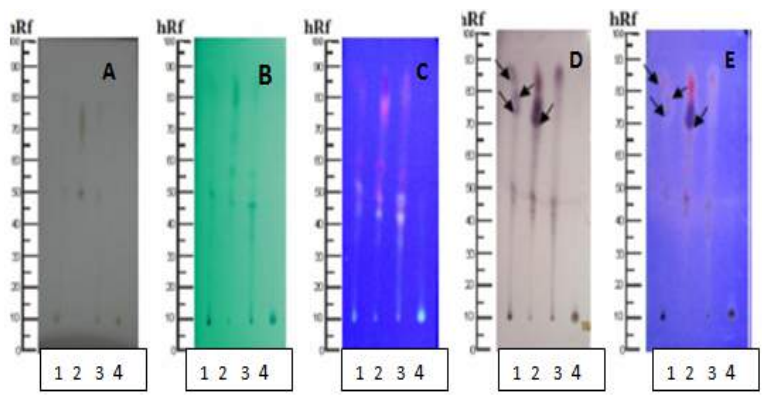

Gambar 1. Kromatogram ekstrak etanolik batang brotowali dan fraksinya sebelum dan setelah disemprot anisaldehida asam sulfat. A. sinar tampak, B. UV 254, C. UV 366m (A, B dan $\mathrm{C}$ dilihat sebelum disemprot), $\mathrm{D}$ sinar tampak dan E UV 366 setelah disemprot, 1. Ekstrak etanol, 2. Fraksi kloroform, 3. Fraksi nheksan dan 4. fraksi etilasetat. Adanya senyawa terpenoid ditunjukkan dengan tanda panah

Pada kromatogram (Gambar 1D) menunjukkan adanya bercak warna biru lemah pada pengamatan sinar tampak di 
fraksi etil asetat. Warna biru lemah merupakan petunjuk adanya senyawa terpenoid dalam ekstrak etanolik, fraksi kloroform, dan fraksi etil asetat (Jork et al., 1989).

Hasil KLT pada Gambar 1D dan 1E menunjukkan bahwa ekstrak etanolik dan fraksi kloroform tampak bercak menjadi berwarna ungu setelah disemprot anisaldehida asam sulfat dibanding bercak awal. Stahl (1985) menyatakan penggunaan pereaksi anisaldehida asam sulfat untuk mengetahui adanya senyawa terpenoid dan bercak (awalnya tidak berwarna) setelah disemprot akan menjadi berwarna ungu, biru, merah, abu-abu atau hijau. Anisaldehid dapat memperpanjang sistem kromofor pada senyawa dan pada ekstrak etanolik juga fraksi kloroform dan etil asetat menunjukkan adanya senyawa golongan terpenoid.

Deteksi keberadaan senyawa golongan flavonoid lempeng KLT diuapi dengan amonia dan disemprot dengan sitroborat (Gambar 2). Semua flavonoid menyebabkan pemadaman, sehingga terlihat bercak biru gelap dengan latar belakang kuning pada lempeng KLT dibawah UV254. Sedangkan pada UV366 flavonoid berfluoresensi kuning, ungu, biru, dan hijau (Wagner et al., 1984).

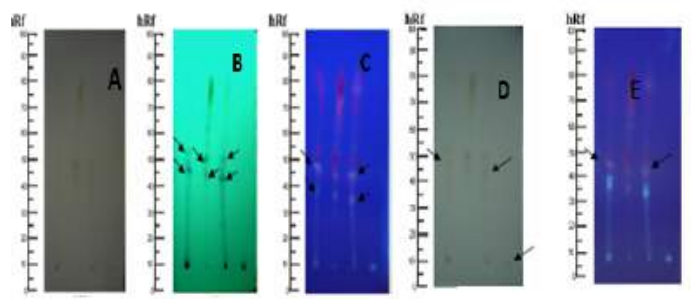

Gambar 2. Kromatogram ekstrak etanolik batang brotowali dan fraksinya pada fase diam silika gel F254, fase gerak toluen:etil asetat:asam asetat (5:4:1) A, sinar tampak, B. UV 254 dan C UV 366 sebelum disemprot sitroborat, D UV 254 stelah disemprot, E, UV 366 setelah disemprot, tanda panah menunjukkan adanya senyawa flavanoid.
Pada gambar 2, kromatogram di bawah sinar UV254 terlihat pemadaman bercak pada ekstrak etanolik; n-heksan, kloroforn dan etilasetat. Suatu senyawa yang meredam pada UV254 memiliki gugus karbonil, fenolik, atau gugus lain yang mengandung setidaknya dua ikatan rangkap terkonjugasi. Pengamatan UV366 terlihat bercak berfluoresensi kuning kehijauan (Gambar 2C) pada ekstrak etanolik. Hal ini menunjukkan adanya kandungan flavonol tanpa $5-\mathrm{OH}$ bebas atau flavonol dengan 5-OH tersubsitusi. Fraksi n-heksana tampak bercak berfluroresensi orange kemerahan. Pada UV366 bercak berfluororesensi menunjukkan adanya ikatan rangkap terkonjugasi yang lebih panjang (Wagner et al, 1996). Setelah dilakukan penyemprotan dengan pereaksi sitroborat pada gambar $2 \mathrm{C}$ dan 2D menunjukkan bahwa pada ekstrak etanolik, fraksi kloroform dan etil asetat terlihat warna kuning yang lebih intens pada pengamatan sinar tampak. Pengamatan UV366 terlihat bercak pada ekstrak etanolik dan fraksi etil asetat berfluoresensi kuning orange (Gambar 2D). dengan deteksi menggunakan penampak noda sitoborat tersebut dimungkinkan ekstrak mengandung senyawa golongan flavonoid.
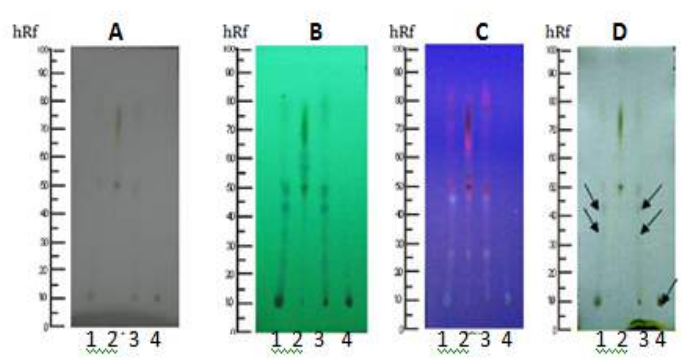

Gambar.3 Kromatogram ekstrak etanolik batang brotowali dan fraksinya sebelum dan setelah disemprotasam fosfomolibdat. A. sinar tampak, B. UV 254, C UV 366m (A,B dan C dilihat sebelum disemprot), $\mathrm{D}$ setelah disemprot, 1. Ekstrak etanol, 2. Fraksi kloroform, 3. Fraksi n-heksan dan 4. fraksi etilasetat. Adanya senyawa reduktor (kumarin) ditunjukkan dengan tanda panah. 
Kromatogram pada Gambar 3C menunjukkan adanya bercak warna biru lemah pada pengamatan sinar tampak di fraksi etilasetat dengan hRf 0 (totolan awal), ekstrak etanolik dan fraksi kloroform dengan hRf 44 dan 50. Warna biru lemah merupakan petunjuk adanya senyawa kumarin yang bersifat reduktor lemah karena dengan pereaksi fosfomolibdat tidak memberikan reduksi yang kuat dan berupa campuran oksidator berwarna biru abu-abu (Jork et al., 1989). Sedangkan kromatogram pada gambar 3D memperlihatkan fraksi etil asetat (hRf 0), ekstrak etanolik dan fraksi etil asetat (hRf 44) menunjukkan fluororesensi hijau pada UV366 yang merupakan adanya senyawa golongan kumarin. Golongan senyawa seperti kumarin, pada kondisi alkalis cincin lakton akan terbuka dan terbentuk anion asam kumarinat kemudian terjadi siklisasi menjadi lakton. Dengan adanya sinar UV, maka anion asam kumarinat akan mengalami isomerisasi menjadi bentuk trans yaitu anion asam-okumarat. Bercak yang mengandung anion asam-o-kumarat terlihat berfluororesensi hijau, hijau biru, kuning atau coklat di bawah sinar UV366 (Machek, 1972).

\section{Uji sitotoksik ekstrak}

Hasil analisis sitotoksik menggunakan metode MTT menunjukkan adanya hubungan antara konsentrasi ekstrak etanol dengan viabilitas sel (Gambar 4). Semakin tinggi konsentrasi ekstrak semakin rendah viabilitas sel. Hasil analisis menunjukkan bahwa ekstrak etanol bersifat sitotoksik dengan nilai $\mathrm{IC}_{50}$ sebesar $314 \mu \mathrm{g} / \mathrm{ml}$. Ekstrak dikatakan toksik jika mempunyai $\mathrm{IC}_{50}$ lebih kecil dari $1000 \mu \mathrm{g} / \mathrm{ml}$ (Mayer dan Gustafson, 2008). Sitotoksisitas yang disebabkan oleh perlakuan ekstrak etanol dapat juga dilihat dari perubahan morfologi sel yang terjadi sejalan dengan peningkatan konsentrasi ekstrak (Gambar 6).

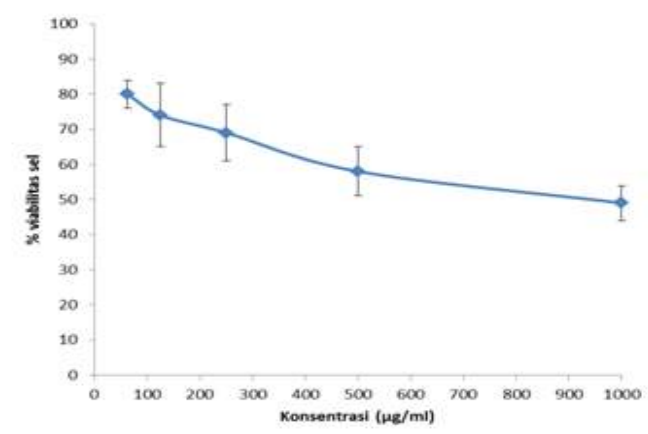

Gambar 4. Kurva efek sitotoksik ekstrak metanol terhadap viabilitas sel dengan metode MTT. Uji dilakukan dengan menginkubasi sel dengan kepadatan $1,5 \times 10^{4}$ dalam plat 96sumuran selama 24 jam dalam media RPMI 1640 untuk beradaptasi. Sel kemudian diberi perlakuan ekstrak dengan konsentrasi 1000, 500, 250, 125 dan $62,5 \mu \mathrm{g} / \mathrm{ml}$ dan diinkubasi selama 24 jam. Viabilitas sel diperoleh dari konversi absorban formazan yang terbentuk akibat perlakuan MTT. Profil viabilitas sel disajikan dari rata-rata \pm standar deviasi (SD) dari 3 perlakuan

\section{Uji sitotoksik fraksi}

Hasil pengamatan uji sitotoksik menunjukkan bahwa fraksi kloroform memberikan efek sitotoksik yang paling kuat dengan nilai $\mathrm{IC}_{50}$ sebesar $148 \mu \mathrm{g} / \mathrm{ml}$ (Gambar 5).

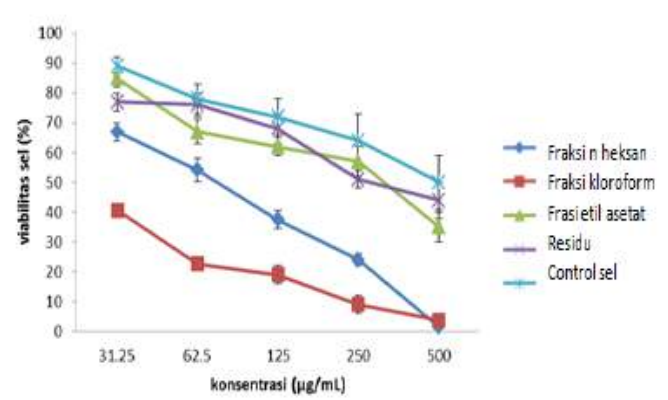

Gambar 5. Kurva efek perlakuan masing masing fraksi terhadap viabilitas sel WiDr. Sel kemudian diberi perlakuan fraksi $n$-heksan, kloroform, etil asetat dan residu dengan konsentrasi 500, 250, 125 dan 62,5 dan 31,25 $\mu \mathrm{g} / \mathrm{ml}$ dan diinkubasi selama 24 jam. Profil 
viabilitas sel disajikan dari rata-rata 3 perlakuan.

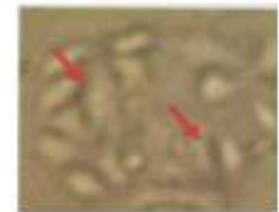

A

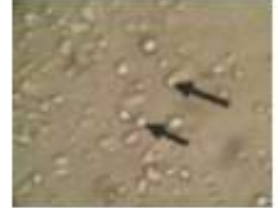

B

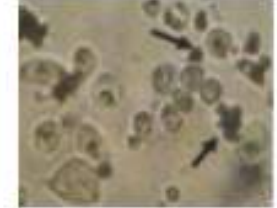

C

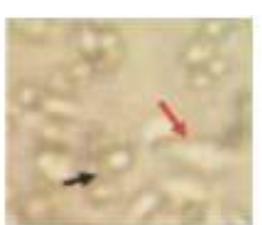

D

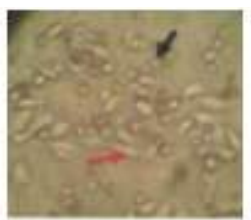

$\mathbf{E}$

Gambar 6. Morfologi sel WiDr dengan perlakuan kloroform dan diinkubasi selama 24 jam, A. kontrol sel, B. perlakuan $500 \mu \mathrm{g} / \mathrm{ml}$, C. perlakuan $250 \mu \mathrm{g} / \mathrm{ml}$, D. perlakuan $125 \mu \mathrm{g} / \mathrm{ml}$, E. perlakuan $62.5 \mu \mathrm{g} / \mathrm{ml}$

Fraksi $n$-heksan, etil asetat, metanol dan residu mempunyai aktivitas yang lebih rendah dengan $\mathrm{IC}_{50}$ berturut-turut sebesar 563; 387; 358 dan $862 \mu \mathrm{g} / \mathrm{ml}$. Fraksi kloroform merupakan fraksi yang paling aktif, hal ini karena fraksi kloroform mengandung senyawa terpenoid dan flavonoid (senyawa fenolik). Karena adanya senyawa yang mengandung gugus hidroksi tersebut mampu membunuh sel.

Aktivitas fraksi aktif (fraksi kloroform) terhadap induksi apoptosis sel WiDr metode double staining

Hasil uji induksi apoptosis dengan pengecatan DNA menggunakan metode double staining dengan etidium bromida dan akridin orange memperlihatkan warna hijau terang pada kontrol sel, sedangkan pada sel dengan perlakuan fraksi disamping sel berwarna hijau terdapat sel yang berwarna orange. Adanya warna orange mengindikasikan sel mengalami apoptosis (Gambar 7).

\section{Induksi apoptosis dengan metode flowcytometri}

Sel yang mengalami induksi apoptosis dapat dikuantitatifkan dengan metode flowcytometri. Hasil analisis menunjukkan bahwa perlakuan fraksi kloroform dan doksorubisin dapat meningkatkan kematian secara, hal ini ditunjukan oleh adanya peningkatan apoptosis pada fraksi kloroform dibanding dengan jumlah sel yang mengalami apoptosis pada kontrol (tabel 2 dan gambar 5) sedangkan peningkatan apoptosis terbesar terjadi pada pemberian doksorubisin (tabel 2). Namun demikian disamping terjadi apoptosis, fraksi kloroform juga menyebabkan kematian secara nekrosis yang hampir sama dengan sel yang mengalami apoptosis yang jumlahnya lebih besar daripada kontrol (18.02\%), sedangkan doksorubisin menyebabkan nekrosis lebih kecil dari pada perlakuan fraksi kloroform (tabel 2)
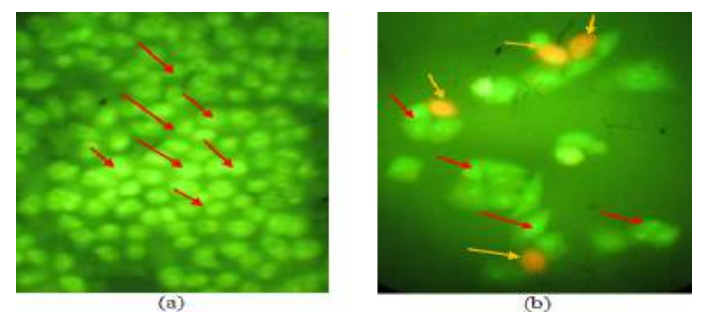

Gambar 7. Hasil pengamatan morfologi sel WiDr dengan pengecatan DNA menggunakan akridine orange - etidium bromida. Pengamatan dilakukan dibawah mikroskop flouresens. (a) Sel kontrol memperlihatkan warna hijau terang yang sama dan berbentuk seperti daun $(\longrightarrow)$ yang menandakan bahwa sel masih hidup, (b) perlakuan isolat aktif, sel WiDr terlihat berwarna orange dengan bentuk yang tidak teratur $(\rightarrow)$ yang mengindikasikan sel mengalami apoptosis. 
Tabel 2. Hasil analisis induksi apoptosis dengan metode flowcytometri

\begin{tabular}{lccc}
\hline Jenis sampel & $\begin{array}{c}\% \\
\text { hidup }\end{array}$ & $\begin{array}{c}\% \\
\text { apoptosis }\end{array}$ & $\begin{array}{c}\% \\
\text { nekrosis }\end{array}$ \\
\hline Kontrol & 61,57 & 17,90 & 18,02 \\
Doksorubisin & 1,55 & 68.12 & 26,77 \\
Fraksi F3 & 46,77 & 29,8 & 28,29 \\
\hline
\end{tabular}

\section{Simpulan}

Ekstrak etanol yang bersifat sitotoksik terhadap sel WiDr dengan $\mathrm{IC}_{50}$ sebesar $314 \mu \mathrm{g} / \mathrm{ml}$. Hasil fraksinasi dari ektrak etanol adalah fraksi $n$-heksan, kloroform, etil asetat dan residu. Fraksi paling aktif adalah fraksi kloroform dengan $\mathrm{IC}_{50}$ sebesar $148 \mu \mathrm{g} / \mathrm{ml}$.

Berdasarkan identifikasi pada kromatogram KLT dengan reagen penampak noda menunjukkan bahwa ekstrak mengandung golongan senyawa terpenoid, flavanoid, dan kumarin yang bersifat reduktor lemah.

Fraksi kloroform menyebabkan kematian sel WiDr secara apoptosis. Pengamatan induksi apoptosis dilakukan secara kualitatif dengan pengecatan etidium bromida-akridin orange pada sel WiDr. Perlakuan Fraksi kloroform memberikan warna orange dan kontrol sel berwarna hijau.

\section{Daftar Pustaka}

Calvert PM, Frucht H., 2002, The genetics of colorectal cancer, Ann Intern Med. 137(7):603-12. doi: $\quad 10.7326 / 0003-4819-137-7-$ 200210010-00012

Dai JR, Hallock YF, Cardellina JH, Boyd MR., 1998, HIV-inhibitory and cytotoxic oligostilbenes from the leaves of Hopea malibato. $J$ Nat Prod. 61(3):351-3. doi: $\underline{10.1021 / \mathrm{np} 970519 \mathrm{~h}}$
Febriansah R, Putri DD, Sarmoko, Nurulita NA, Meiyanto E, Nugroho AE., 2014, Hesperidin as a preventive resistance agent in MCF-7 breast cancer cells line resistance to doxorubicin. Asian Pac J Trop Biomed. 4(3):228-33. doi: 1691(14)60236-7

Harborne JB, 1987, Metode Fitokimia Penuntun Modern menganalisis tumbuhan, Edisi II, Penerbit ITB. Bandung.

Irianti, T., Andayana, P., Suryani, E., 2011, Aktivitas Penangkapan Radikal 2,2-Difenil-1Pikrilhidrazil Oleh Ekstrak Etanolik Batang Brotowali (Tinospora crispa (L.) Miers) Dan Fraksi-Fraksinya, Majalah Obat Tradisional 16(3): 139 $146 . \quad$ doi: 10.22146/tradmedj.8850

Jork, H., Funk, W., Fischer, W., dan Wimmer, H., 1989, Thin Layer Chromatography Reagents and Detection Methods, 377, Bassel, New York.

Machek, K., 1972, Pharmaceutical Application of Thin Layer and Paper Chromatography, 63-565, Elsevier Publishing Company, London.

Mayer AM, Gustafson KR. 2008, Marine pharmacology in 20052006: antitumour and cytotoxic compounds. Eur J Cancer. 2008 Nov;44(16):2357-87. doi: 0.1016/j.ejca.2008.07.001

Ries LAG, Eisner MP, Kosary CL, Hankey BF, Miller BA, Clegg L, Mariotto A, Feuer EJ, Edwards BK (eds). SEER Cancer Statistics Review, 1975-2002, National Cancer Institute. Bethesda, MD, https://seer.cancer.gov/archive/csr/ 1975_2002/, based on November 2004 
Saphiro GI, Harper JW. 1999. Anticancer Drugs Targets, Cell Cycle and Checkpoint Control. $J$ Clin Invest. 104(12): 1645-53. doi: 10.1172/JCI9054

Schneider, K., A. 1997. Cancer genetics, encyclopedia of human biology, second edition, 312-314. Academic Press. New York.

Stahl, E., 1985, Analisis Obat Secara Kromatografi dan Mikroskopi, diterjemahkan oleh Kosasih Padmawinata, 1-17, Penerbit ITB, Bandung.

Triastuti, A., 2010, Antiangiogenic Effect of the Chloroform Extract of Tinospora Crispa (L.) Miers Stem in the Chick Embryo Chorioallantoic Membrane (CAM) Induced by BFGF. Eksakta, 11(2).

Wagner, H., Bladt, S., and Zgainski, E.M., 1996, Plant Drug Analysis, 23-26, Springer-Verlag Berlin Hiedelberg, New York.

Warsinah, Baroroh, H. N., Harwoko, 2014, penelusuran Senyawa bioaktif pada Batang Brotowali (Tinospora crispa L) Sebagai Bahan Antikanker. Laporan Penelitian Dasar. Disimpan di Lembaga Penelitian dan Pengabdian Masyarakat, Universitas Jenderal Soedirman, Purwokerto.

Zulkhairi, A., Abdah, A., Kamal, N.H., Nursakinah, Moklas MA, Hasnah, B., Fazali F., Khairunnur T.A., Kamil K.H., Zamree M.S., Shahidan MMA, 2008, Biologial properties of Tinospora crispa (Akar Patawali) and its antiproliferative activities on selected human cancer cell lines, Malays J Nutr. 14(2): 173-87. 